\title{
BEAUFILS RANGES TO ASSESS THE COTTON NUTRIENT STATUS IN THE SOUTHERN REGION OF MATO GROSSO(1)
}

\author{
Ademar Pereira Serra( ${ }^{(2)}$, Marlene Estevão Marchetti(3), Enrique Pouyú \\ Rojas $^{(4)}$ \& Antônio Carlos Tadeu Vitorino( ${ }^{(3)}$
}

\begin{abstract}
SUMMARY
The relationships between nutrient contents and indices of the Diagnosis and Recommendation Integrated System (DRIS) are a useful basis to determine appropriate ranges for the interpretation of leaf nutrient contents. The purpose of this study was to establish Beaufils ranges from statistical models of the relationship between foliar concentrations and DRIS indices, generated by two systems of DRIS norms - the F value and natural logarithm transformation - and assess the nutritional status of cotton plants, based on these Beaufils ranges. Yield data from plots (average acreage $100 \mathrm{ha}$ ) and foliar concentrations of macro and micronutrients of cotton (Gossypium hirsutum r. latifolium) plants, in the growing season 2004/2005, were stored in a database. The criterion to define the reference population consisted of plots with above-average yields +0.5 standard deviation (over $4,575 \mathrm{~kg} \mathrm{ha}^{-1}$ seed cotton yield). The best-fitting statistical model of the relationship between foliar nutrient concentrations and DRIS indices was linear, with $R^{2}>0.8090, p<0.01$, except for $N$, with $R^{2}=0.5987, p<0.01$. The two criteria were effective to diagnose the plant nutritional status. The diagnoses were not random, but based on the effectiveness of the chi-square-tested method. The agreement between the methods to assess the nutritional status was 92.59-100 \%, except for $\mathrm{S}$, with $74.07 \%$ agreement.
\end{abstract}

Index terms: Mineral nutrition, Gossypium hirsutum r. latifolium, leaf analysis, DRIS.

\footnotetext{
(1) Part of the Doctorate of the first author in the Universidade Federal da Grande Dourados - UFGD. Supported by Brazilian Federal Agency for Support and Evaluation of Graduate Education-CAPES. Received for publication in April 11, 2011 and approved in November 11, 2011.

(2) EMBRAPA-CNPGC. BR 262, Post Office Box 154, CEP 79002-970 Campo Grande (MS). E-mail: ademar.serra@cnpgc.embrapa.br

(3) Professor of Agrarian Science Faculty, Universidade Federal da Grande Dourados - UFGD. Street João Rosa Gões, number 1761, Progress Village, CEP 79825-070 Dourados (MS). E-mails: marlenemarchetti@ufgd.edu.br; antoniovitorino@ufgd.edu.br

(4) Consultant in agronomy. BR 163, Post Office Box 22, CEP 78725-500, Rondonópolis (MT). E-mail: epouyu@yahoo.com.br
} 


\title{
RESUMO: FAIXAS DE BEAUFILS PARA AVALIAÇÃO DO ESTADO NU- TRICIONAL DO ALGODOEIRO NA REGIÃO SUL DO MATO GROSSO
}

\begin{abstract}
A relação entre teores de nutrientes e indices DRIS é uma prática útil para determinar faixas adequadas para a interpretação dos teores foliares dos nutrientes. Objetivo na realização desse trabalho foi criar as faixas de Beaufils a partir de modelos estatísticos da relação entre teores foliares e indices DRIS, gerados por dois sistemas de normas DRIS: valor $F$ e transformação por logaritmo natural, bem como avaliar o estado nutricional do algodoeiro, por meio das faixas de Beaufils. Dados de produtividade, de parcelas com médias de 100 ha, e teores foliares de macro e micronutrientes do algodoeiro (Gossypium hirsutum $r$. latifolium), procedente da safra de 2004-2005, foram selecionados para compor a base de dados. O critério para definir a população de referência consistiu nos talhões que apresentavam produtividades acima da média $+0,5$ desvio-padrão $\left(4.575 \mathrm{~kg} \mathrm{ha}^{-1}\right.$ de algodão em caroço). O modelo estatístico da relação entre teores foliares de nutrientes $e$ indices DRIS que teve o melhor ajuste foi o linear, com $R^{2}>0,8090, p<0,01$, com exceção do $N$, que apresentou $R^{2}=0,5987, p<0,01$. Os dois critérios foram eficientes em diagnosticar o estado nutricional da planta; os diagnósticos não foram ao acaso, e sim baseados na eficácia do método que foi testado pelo teste do qui-quadrado. A concordância entre os métodos, na avaliação do estado nutricional, esteve entre 92,59 e $100 \%$, com exceção do $S$, que mostrou $74,07 \%$ de concordância.
\end{abstract}

Termos de indexação: nutrição mineral, Gossypium hirsutum r. latifolium, diagnose foliar, DRIS.

\section{INTRODUCTION}

To interpret the results of traditional chemical analyses of plant tissue for the assessment of the nutritional status of cotton plants, the methods critical level and sufficiency range are used. They are called univariate methods, because only the individual concentration of the nutrients in leaf tissue is taken into consideration while no information about the nutritional balance is provided. The Diagnosis and Recommendation Integrated System (DRIS) (Beaufils, 1973) is an alternative to these traditional appraoches. It relates the nutrient contents in dual ratios, enabling the evaluation of the nutritional balance of a plant, ranking the nutrient levels in relative order, from the most deficient to the most excessive.

Underlying the DRIS is the concept of nutrient balance in plant tissue (Baldock \& Schulte, 1996). To be able to determine the nutritional balance, the DRIS index must be determined for each element in the chemical analysis of plant tissue. The indices are derived from the arithmetic mean of the DRIS functions in which the element is involved.

The calculated deviation between the dual ratios of the sample and the same ratios of DRIS norms is positive or negative, depending on the direction of the dual ratios in relation to the norm. When the values of these indices approach zero, the dual ratios of the sample are similar to the DRIS norms, in other words, the closer to zero the indices, the lower is the nutritional imbalance (Beaufils, 1973).

Based on this principle, statistical models have been adjusted, proposing relationships between DRIS indices and foliar nutrient concentrations (Wadt et al., 1998; Urano et al., 2006, Serra et al., 2010b).

Since the optimal nutrient content corresponds to a DRIS index of zero, statistical models can be adjusted to determine the appropriate nutrient ranges. Beaufils (1973) stated that the standard deviation (s) of the normal nutrient ranges would be between $-4 / 3$ and $4 / 3$; levels below the minimum are considered deficient and above the maximum, excessive. This method is defined in the literature as Beaufils ranges.

The development of normal nutrient ranges for each production region is of utmost importance, since it is observed that farmers use tables based on sufficiency ranges of regions other than the production site. Beaufils ranges are useful because farmers can determine the nutritional status of a crop in a simple way, based on leaf analysis, comparing the foliar contents with the Beaufils ranges.

The purpose of this study was to develop Beaufils ranges based on statistical models of the relationship between foliar concentrations and DRIS indices, generated by two systems of DRIS norms - the F value and natural log transformation - and use these 
Beaufils ranges to assess the nutritional status of cotton in southern region of Mato Grosso.

\section{MATERIALS AND METHODS}

This study was performed with data from commercial cotton fields, of the growing season 2004/2005, in southern region of Mato Grosso, (approximately $12^{\circ} 41^{\prime} \mathrm{S}, 45^{\circ} 40^{\prime} \mathrm{W}$, average altitude $497 \mathrm{~m}$ asl). The soil of the study area was predominantly Oxisol (Embrapa, 2006). Yield data of the conventionally tilled varieties DeltaOpal, DeltaPenta, DeltaPine Acala 90, CNPA ITA 90, and FiberMax 966 were compiled in a database.

To constitute the database, 108 samples of complete leaves (blade + petiole), of which each consisted of 30 single samples, were randomly selected in each commercial plot (average acreage $100 \mathrm{ha}$ ). One sample per plant was taken from the fifth leaf on the main stem (Malavolta, 2006), during flowering of the crop (stages F1 to F4), according to the classification of Marur \& Ruano (2001). The samples were dried in a forced-air oven at $65{ }^{\circ} \mathrm{C}$ to constant weight, ground and sieved $\left(60 \mathrm{mesh} \mathrm{cm}^{-2}\right)$. The seed cotton yield was evaluated at the end of the cycle, after harvesting the plots with a combine harvester.

In the leaf samples, the total contents of N, P, K, $\mathrm{Ca}, \mathrm{Mg}, \mathrm{S}, \mathrm{B}, \mathrm{Zn}, \mathrm{Cu}, \mathrm{Mn}$, and Fe were determined by the method described by Malavolta et al. (1997). The information stored in the database and used for DRIS were the total leaf contents of macronutrients $\left(\mathrm{g} \mathrm{kg}^{-1}\right)$ and micronutrients $\left(\mathrm{mg} \mathrm{kg}^{-1}\right)$ and seed cotton yield ( $\left.\mathrm{kg} \mathrm{ha}^{-1}\right)$. The database was divided into two subpopulations, using the mean +0.5 standard deviation as criterion to separate the populations (Silva et al., 2005; Urano et al., 2006, 2007) into a high-yielding group (over 4,575 $\mathrm{kg} \mathrm{ha}^{-1}$ (mean +0.5 standard deviation) and one with seed cotton yield below $4,575 \mathrm{~kg} \mathrm{ha}^{-1}$.

Two methods were used to choose the norms (mean and standard deviation of the ratios between nutrients in the reference population), and the method determined by the F value (Jones, 1981; Letzsch, 1985, Walworth \& Sumner, 1987) and transformation by natural log (NL) of the ratios between the nutrient concentrations (Urano et al., 2006, 2007, Serra et al., 2010a,b).

The determination of the ratio (A/B or $\mathrm{B} / \mathrm{A})$ to establish the norm by the variance ratio method, the $\mathrm{F}$ value, was defined as the variance ratio of the low-yielding (non-reference) and high-yielding population (reference), and the order of the ratio with the highest value was chosen among the variance ratios (Jones, 1981; Letzsch, 1985; Walworth \& Sumner, 1987).
The second approach consisted of the natural log transformation (NL) of the ratios between nutrient contents in the reference population, directly using the ratios between nutrients $(\mathrm{A} / \mathrm{B})$, since, when $\mathrm{NL}$ is used for the dual ratios, be it the $\operatorname{direct}(\mathrm{A} / \mathrm{B})$ or the inverse form $(\mathrm{B} / \mathrm{A})$, both have the same numerical value, changing only the sign (+ or -).

In each sample to be assessed, the deviations (DRIS functions) of these sample from the average values of the same ratios in the reference population were determined according to Jones (1981), in units of standard deviation (s) using an adjustment factor (c) = 1, as suggested by Alvarez V. \& Leite (1999):

$$
f\left(\frac{\mathrm{A}}{\mathrm{B}}\right)=\left[\left(\frac{\mathrm{A}}{\mathrm{B}}\right)-\left(\frac{\mathrm{a}}{\mathrm{b}}\right)\right] \cdot\left(\frac{\mathrm{c}}{\mathrm{s}}\right)
$$

The DRIS indices were calculated following the general formula proposed by Beaufils (1973), where for nutrient A:

$$
\text { DRIS Index } A=\frac{\sum f\left(\frac{\mathrm{A}}{\mathrm{B}}\right)-\sum f\left(\frac{\mathrm{B}}{\mathrm{A}}\right)}{n}
$$

$n=$ number of DRIS functions involved in the analysis.

After the individual assessment of the model fitting of regression equations between foliar nutrient concentrations and DRIS indices, by the two determination methods of the DRIS norms (F value and $\mathrm{NL}$ ), the identity of the methods was tested. The approach based on the $\mathrm{F}$ value was considered standard $\left(Y_{1}\right)$, and then compared with the alternative method NL $\left(Y_{j}\right)$. For the identity test, the statistical procedure proposed by Leite \& Oliveira (2002) was used.

The above procedure was used to test the identity of two analytical methods $\left(Y_{1} Y_{j}\right)$, using a combination of the $\mathrm{F}$ statistic $\left[\mathrm{F}\left(\mathrm{H}_{0}\right)\right]$, as modified by Graybill (1976), test of the mean error $\left(t_{\bar{e}}\right)$ and of the linear correlation coefficient $\left(\mathrm{r}_{\mathrm{Y} 1 \mathrm{Yj}}\right)$.

Based on these statistics, we propose a decision rule for testing the hypothesis of identity between any two analytical methods, ie, groups of values.

The identity between $\mathrm{Y} 1$ and $\mathrm{Yj}$ was tested by the model $Y_{\mathrm{j}}=\beta b_{0}+\beta b_{1} Y_{1}+e_{\mathrm{i}}$. The hypothesis $H_{0}: \beta b_{0}=0$ e $\beta b_{1}=1$ was adjusted and then tested by comparison with the $\mathrm{F}\left(H_{0}\right)$ statistic of Graybill (1976) with the tabulated value $\mathrm{F}_{0,01}(2, \mathrm{n}-2)$ and the MSres (residual mean square of the regression);

$$
F\left(H_{0}\right)=\frac{(\beta-\theta)^{\prime}\left(\mathrm{Y}_{1}{ }^{\prime} \mathrm{Y}_{1}\right)(\beta-\theta)}{2 M S \operatorname{Re} s} \sim \mathrm{F}_{\alpha}(2, n-2 \text { G.L. })
$$

The condition set for identity between the methods was: $\mathrm{F}\left(\mathrm{H}_{0}\right) \mathrm{S}<\mathrm{F}_{0,01}(2, \mathrm{n}-2), \bar{e}=0$ (non- 
significant) and $\mathrm{r}_{\mathrm{YjY} 1}>(1-|\bar{e}|)$; it was assumed that the result would be $Y_{\mathrm{j}}=Y_{1}$ for a significance level of $1 \%$, where:

$$
{ }^{\tau_{Y_{j}} Y_{l}}=\frac{\operatorname{Cov}\left(Y_{j}, Y_{1}\right)}{\sqrt{V\left(Y_{\mathrm{j}}\right) V\left(Y_{1}\right)}} \therefore \bar{e}=\frac{\sum \frac{Y_{j i}}{Y_{1 i}}}{n}
$$

To test the hypothesis $\mathrm{H}_{0}: \bar{e}=0$, the statistic $t \bar{e}=\frac{\bar{e}-0}{S_{\bar{e}}}$ was used with $S_{\bar{e}}=\frac{S_{e}}{\sqrt{n}}$; adopting $\mathrm{n}-1$ degrees of freedom and $\alpha=1 \%$. If $t \bar{e} \geq \mathrm{t}_{\alpha}(n-1)$, the hypothesis $\mathrm{H}_{0}$ is rejected. On the other hand, if $\mathrm{t} \bar{e}<\mathrm{t}_{\alpha}(n-1)$, the hypothesis $\mathrm{H}_{0}$ is accepted, indicating that the observed difference between the two methods was random and that the approaches are identical, however, the decision of the identity test equations must be based on the other criteria, $\mathrm{F}\left(\mathrm{H}_{0}\right)$ and $\mathrm{r}_{\mathrm{Yj} Y 1}$, as well.

The DRIS indices were interpreted by the Beaufils ranges, by forming five classes, according to the standard deviation range (s) of DRIS indices from the reference population, where: deficient nutritional status $<-4 / 3 \mathrm{~s}$; deficiency-prone $=-4 / 3$ to $-2 / 3 \mathrm{~s}$; sufficient $=-2 / 3$ to $2 / 3 \mathrm{~s}$; tendency to excess $=2 / 3 \mathrm{~s} 4 / 3 \mathrm{~s}$; excessive levels $>4 / 3 \mathrm{~s}$.

For both methods, the hypothesis whether the frequency at which each nutrient appeared as deficient had been randomly attributed was tested. For this purpose, the chi-square test $\left(\chi^{2}\right)$ of Pearson was applied at $1 \%$ probability, with n-1 degrees of freedom ( $\mathrm{n}=$ number of analyzed nutrients). If the hypothesis were true, the observed frequencies for all nutrients would be statistically equal to each other (Urano et al., 2006; Serra et al., 2010a). The expected $(E F)$ and observed frequencies $(O F)$ were calculated as follows:

$$
\begin{gathered}
E F(\%)=\left[\left(\frac{\text { Total number of plots evaluated }}{\text { Number of nutrients evaluated }}\right) /(\text { Total number of plots evaluated })\right] 100 \\
\text { OF }(\%)=\left(\frac{\text { Total number of } \text { plots evaluated }}{\text { Number of nutrients evaluated }}\right) 100 \\
\chi^{2}=\sum_{i=1}^{k}\left[\frac{\left(O F_{i}-E F_{i}\right)^{2}}{E F_{i}}\right]
\end{gathered}
$$

The assessment of the nutritional status by the two methods was compared by the frequency of coincident diagnoses obtained by the norms defined by the $\mathrm{F}$ value and those obtained by natural log transformation (NL).

Statistical analysis was performed using the program SAEG 9.1 (Ribeiro Junior, 2001), and the other DRIS calculations with Excel ${ }^{\circledR}$ (2010) spreadsheets (Microsoft Corporation, 2010).

\section{RESULTS AND DISCUSSION}

The relationship between DRIS index and foliar nutrient allowed two fittings of equations, linear and quadratic (Figures 1, 2, 3, and 4). Silveira et al. (2005a) stated that the best-fitting model was linear and logarithmic, as also reported by Guindani et al. (2009).
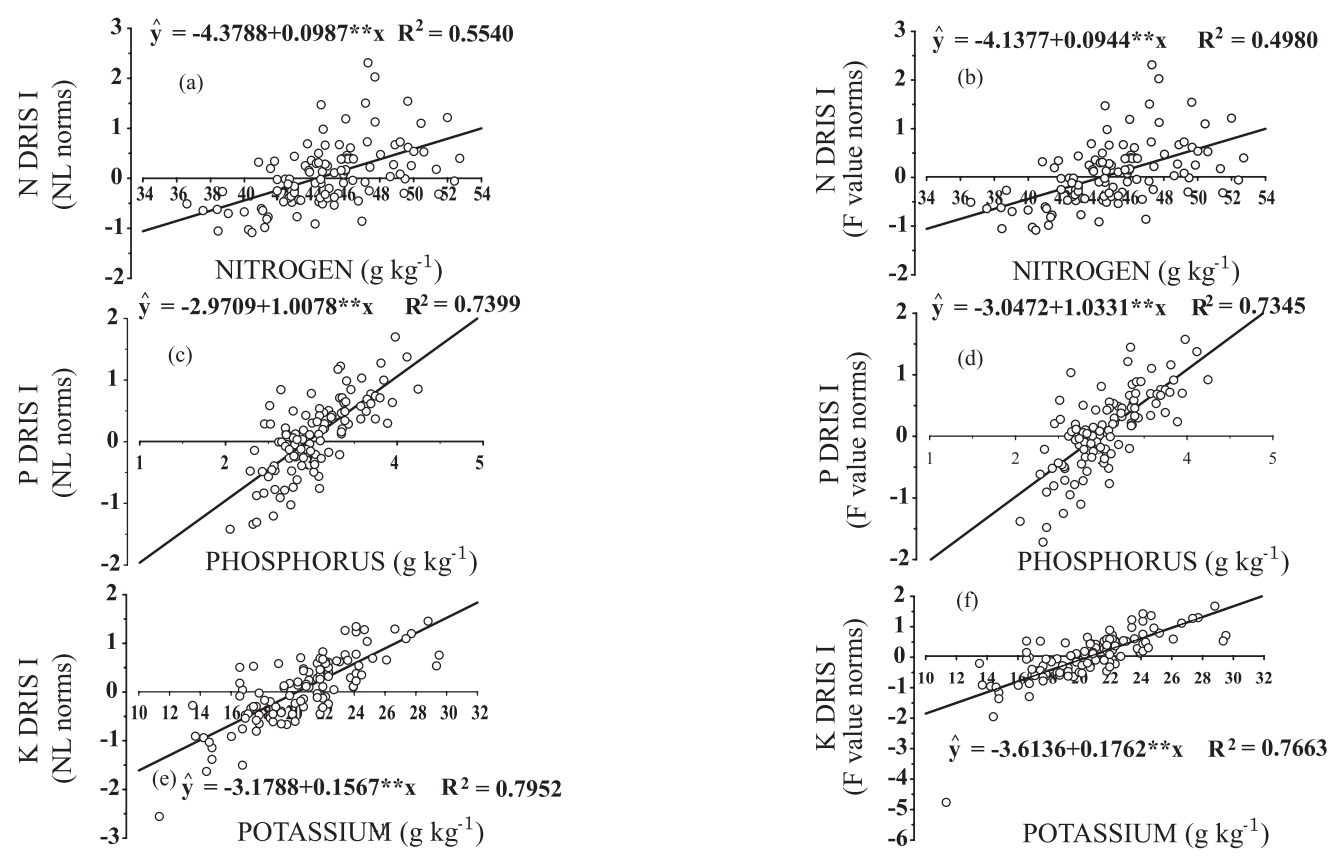

Figure 1. Relationship between the primary macronutrient (reference and non-reference population) and their respective DRIS indices (DRIS I), generated by the norms based on the criterion of natural log transformation (NL) (a, c and e) and the norms determined by the $\mathrm{F}$ value (b, $d$ and $\mathrm{f}$ ). ** Indicates $\mathrm{p}<\mathbf{0 . 0 1}$. 

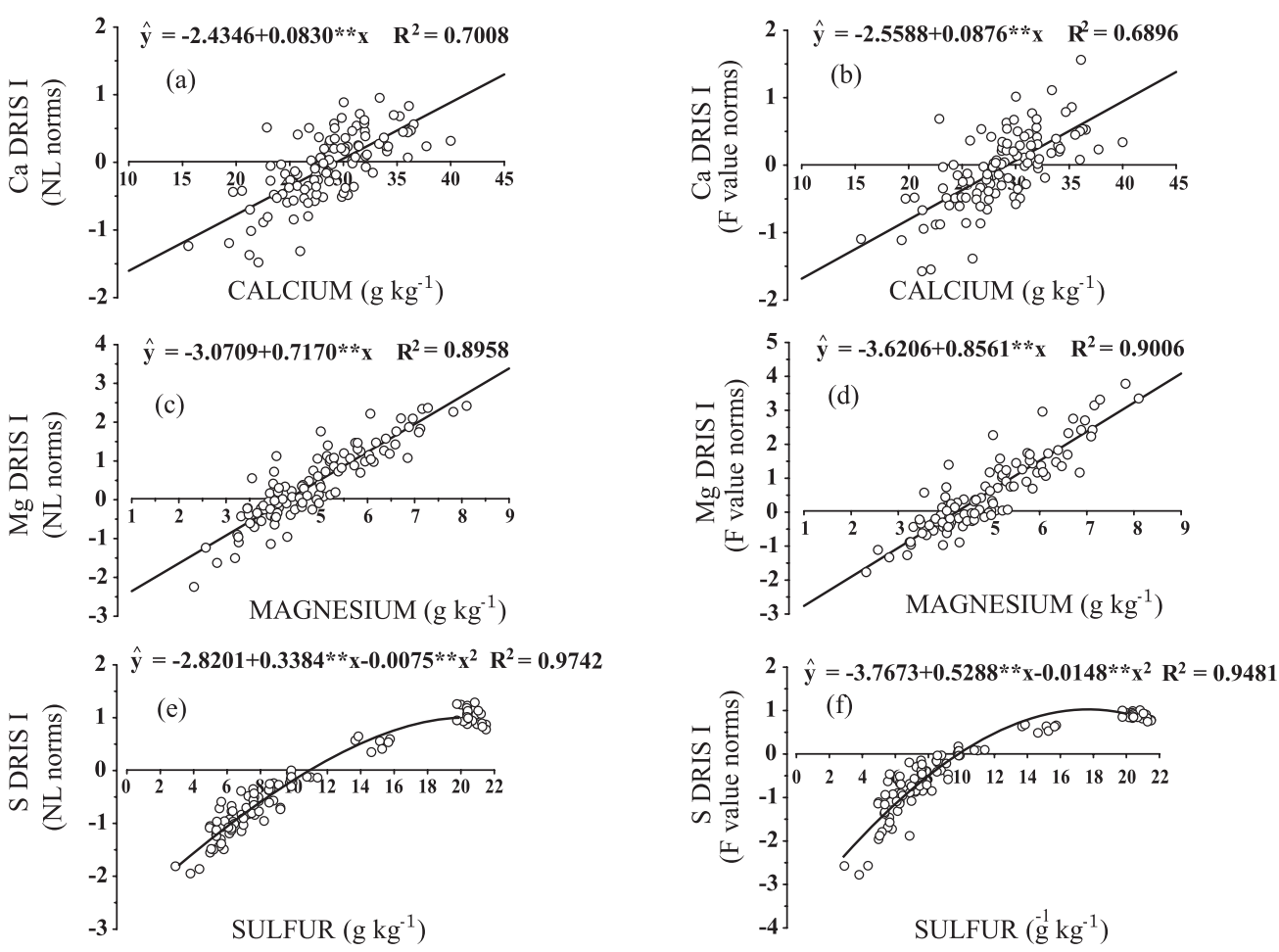

Figure 2. Relationship between the macronutrient levels (reference and non-reference population) and their respective DRIS indices (DRIS I), generated by the norms based on the criterion of natural log transformation (NL) (a, c and e) and the norms defined by $F$ value (b, $d$ and $f$ ). $* * p<0.01$.
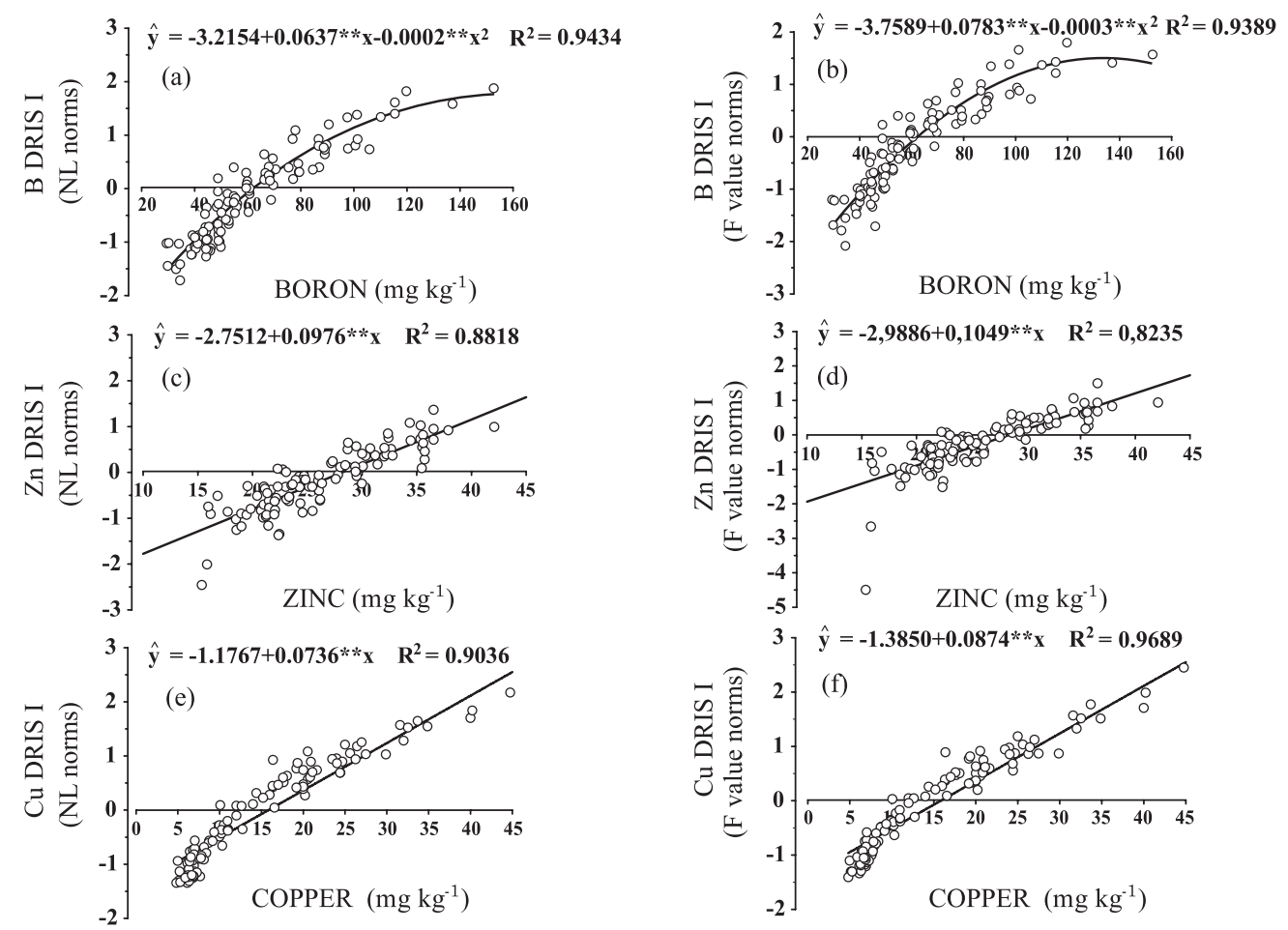

Figure 3. Ratio between the levels of the micronutrients (reference and non-reference population), boron, zinc and copper and their respective DRIS indices (DRIS I), generated by the norms based on the criterion of natural log transformation (NL) (a, $c$ and e) and the norms defined by the $F$ value (b, $d$ and f). $* * \mathrm{p}<0.01$. 

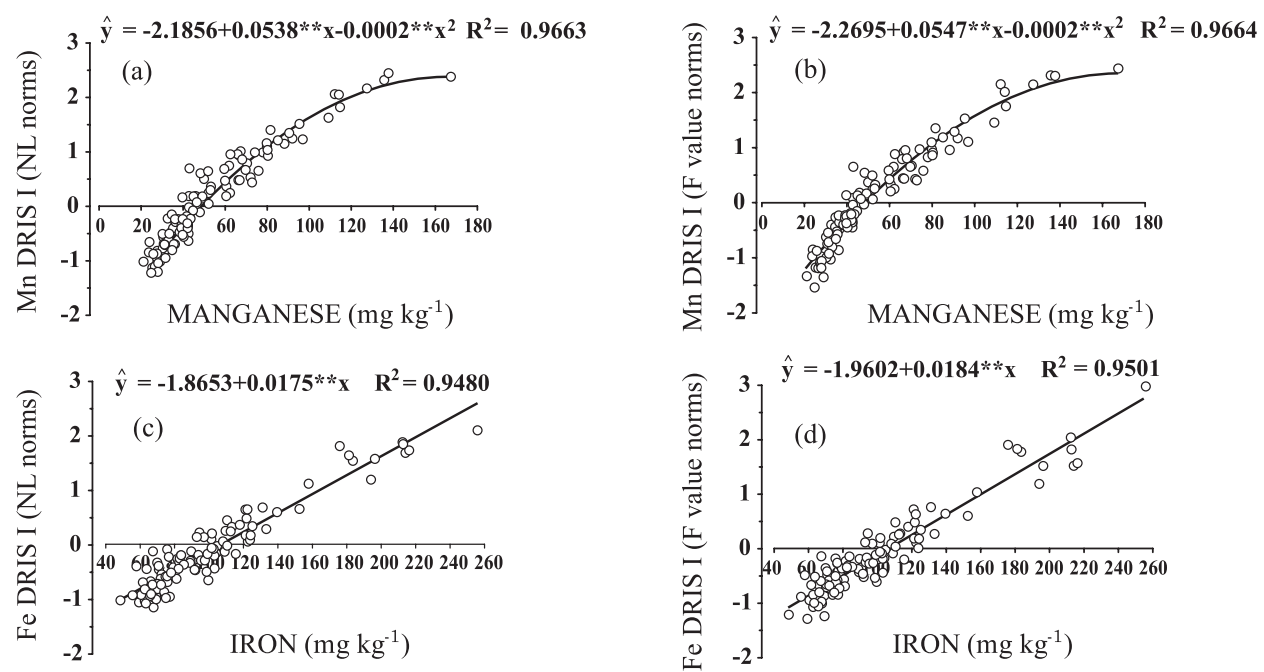

Figure 4. Ratio between the levels of micronutrients (reference and non-reference population), manganese (Mn) and iron (Fe) and their respective DRIS indices (DRIS I), generated by the norms based on the criterion of natural log transformation (NL) (a and c) and the norms defined by $F$ value (b and $\mathrm{d})$. ** $\mathrm{p}<0.01$.

The micronutrients had a greater coefficient of determination $\left(\mathrm{R}^{2}\right)$ than the macronutrients, (over 0.90, p < 0.001), except for Zn (Figure 3c,d), which shows that there is greater dependency of the DRIS indices on the content of the element itself than on the other nutrients involved in the calculation of DRIS indices (Figures 3 and 4).

It was noted that the relationship between DRIS indices and foliar concentrations was significant $(p<0.01)$ for all nutrients. Lowest DRIS indices were associated with the lowest leaf levels, increasing the reliability of the DRIS norms, since the approaches indicated the nutritional limitations correctly (Figures 1, 2, 3 and 4). However, $\mathrm{N}$ was the nutrient with the lowest $R^{2}$ (Figure 1a,b).

Reis Júnior et al. (2002) found a strong positive correlation $(p<0.01)$ between foliar concentrations and the DRIS index, confirming the hypothesis that the system effectively diagnoses the nutritional status. However, they observed the lowest correlation coefficients ( 0.47 and 0.55 , respectively) for the nutrients $\mathrm{N}$ and S. In addition, Silveira et al. (2005a), Nachtigall \& Dechen (2007b), and Guindani et al. (2009) also reported this performance for $\mathrm{N}$.

The coefficient of determination $\left(R^{2}\right)$ is an important parameter to indicate the model fitting of regression equations, however, this parameter alone is not sufficient to define whether two tested methods are identical or not. Thus, the hypothesis of identity was tested for the two analytical methods, as proposed by Leite \& Oliveira (2002).

In the identity test (Table 1 ), the $\mathrm{F}\left(\mathrm{H}_{0}\right)$ value was between $6.24^{* *}$ and $91.85^{* *}$, significant at $1 \%$ probability. This test result for $\mathrm{F}\left(\mathrm{H}_{0}\right)$ showed that the hypothesis $H_{0}: \beta_{0}=0$ e $\beta_{1}=1$ was rejected, accepting the alternative hypothesis that $\beta_{0}$ and $\beta_{1}$ are different from 0 and 1 , respectively. In the test of mean error $\left(t_{\bar{e}}\right)$, no significance was found, in other words, the observed differences between methods were caused randomly, however, the value of $r_{\mathrm{YjY} 1} \geq(1-|\bar{e}|)$ was higher in most cases, except for $\mathrm{Zn}$.

Taking into account the parameters of the identity test proposed by Leite \& Oliveira (2002) for decision making, it was concluded that the two tested methods of choice for DRIS norms, $F$ value and NL, result in different DRIS indices, which are not coincident (Table 1). Therefore, according to Leite \& Oliveira (2002), the projected values of DRIS indices would be coincident if: $\mathrm{F}\left(\mathrm{H}_{0}\right.$ were not significant at $1 \%$ probability; te not significant at $1 \%$ probability, and $\mathrm{r}_{\mathrm{YjY} 1} \geq(1-|\bar{e}|)$. Since no such situation occurred, it was concluded that the tested methods were not identical.

Taking into account that the plant is nutritionally balanced when the DRIS indices are close to zero (Walworth \& Sumner, 1987; Beverly, 1991), the leaf nutrient concentrations were established according to this point of nutritional balance.

Based on the relationship between DRIS indices and nutrient contents in leaf samples of the highyielding population, it was possible to determine the normal nutrient ranges, the so-called Beaufils ranges. The best-fitting statistical model was linear, $p<0.01$ (Table 2) and used to generate the ranges (Table 3), following the recommendations of Beaufils (1973).

The two ways of calculating the norms resulted in similar Beaufils ranges, not dissenting from each other (Table 3). The coefficient of determination $\left(\mathrm{R}^{2}\right)$ 
Table 1. Results of the identity test ${ }^{(1)}$ of the analytical models $(Y 1 Y j)$

\begin{tabular}{|c|c|c|c|c|c|c|c|c|c|}
\hline \multicolumn{2}{|c|}{ Method } & \multirow{2}{*}{$\beta_{0}$} & \multirow{2}{*}{$\beta_{1}$} & \multirow{2}{*}{$r_{Y_{j} Y_{1}}$} & \multirow{2}{*}{$\begin{array}{c}\text { Mean error } \\
(\bar{e})\end{array}$} & \multirow{2}{*}{$\mathbf{F}\left(\mathbf{H}_{0}\right)$} & \multirow{2}{*}{$t \bar{e}$} & \multirow{2}{*}{$\begin{array}{c}r_{Y_{j} Y_{1}} \\
(1-|\bar{e}|)\end{array}$} & \multirow{2}{*}{ Conclusion } \\
\hline $\begin{array}{r}\text { Standard } \\
\text { DRI }\end{array}$ & $\begin{array}{l}\text { lternative } \\
\text { ndex }\end{array}$ & & & & & & & & \\
\hline $\mathrm{F}$ value $\mathrm{N}$ & NL N ${ }^{(2)}$ & 0.0065 & $1.075^{* *}$ & 0.9931 & -0.1035 & $32.06^{* *}$ & $-1.424^{\mathrm{ns}}$ & Yes & $Y_{j} \neq Y_{1}$ \\
\hline $\mathrm{F}$ value $\mathrm{P}$ & NL P & -0.0018 & $1.026^{* *}$ & 0.9935 & 0.0111 & $31.81^{* *}$ & $0.203^{\mathrm{ns}}$ & Yes & $\mathrm{Y}_{\mathrm{j}} \neq \mathrm{Y}_{1}$ \\
\hline $\mathrm{F}$ value $\mathrm{K}$ & NL K & -0.0397 & $1.126^{* *}$ & 0.9650 & -0.0401 & $33.20^{* *}$ & $-0.452^{\mathrm{ns}}$ & Yes & $Y_{j} \neq Y_{1}$ \\
\hline $\mathrm{F}$ value $\mathrm{Ca}$ & NL Ca & -0.0114 & $0.919^{* *}$ & 0.9856 & -0.1189 & $14.29^{* *}$ & $-0.761^{\mathrm{ns}}$ & Yes & $Y_{j} \neq Y_{1}$ \\
\hline $\begin{array}{l}\mathrm{F} \text { value } \\
\mathrm{Mg}\end{array}$ & NL Mg & 0.0574 & $1.1671^{* *}$ & 0.9825 & -0.0598 & $91.85^{* *}$ & $-1.134^{\mathrm{ns}}$ & Yes & $\mathrm{Y}_{\mathrm{j}} \neq \mathrm{Y}_{1}$ \\
\hline $\mathrm{F}$ value $\mathrm{S}$ & NL S & 0.2177 & $-0.2903^{* *}$ & 0.9705 & -0.2933 & $6.24^{* *}$ & $-0.594^{\mathrm{ns}}$ & Yes & $\mathrm{Y}_{\mathrm{j}} \neq \mathrm{Y}_{1}$ \\
\hline $\mathrm{F}$ value $\mathrm{Cu}$ & $\mathrm{NL} \mathrm{Cu}$ & 0.015 & $1.0742^{* *}$ & 0.9667 & 0.0941 & $17.13^{* *}$ & $3.53^{\mathrm{ns}}$ & Yes & $Y_{j} \neq Y_{1}$ \\
\hline $\mathrm{F}$ value $\mathrm{B}$ & NL B & -0.0231 & $1.0444^{* *}$ & 0.9912 & -0.0046 & $15.72^{* *}$ & $-0.08^{n s}$ & Yes & $Y_{j} \neq Y_{1}$ \\
\hline $\mathrm{F}$ value $\mathrm{Fe}$ & NL Fe & 0.0063 & $1.0414^{* *}$ & 0.9892 & 0.0505 & $9.98^{* *}$ & $0.60^{\mathrm{ns}}$ & Yes & $Y_{j} \neq Y_{1}$ \\
\hline $\mathrm{F}$ value $\mathrm{Zn}$ & NL Zn & -0.0248 & $1.1144^{* *}$ & 0.9683 & 0.0111 & $31.81^{* *}$ & $0.203^{\mathrm{ns}}$ & No & $\mathrm{Y}_{\mathrm{j}} \neq \mathrm{Y}_{1}$ \\
\hline $\mathrm{F}$ value $\mathrm{Zn}$ & NL Mn & -0.0523 & $1.0007^{* *}$ & 0.9936 & 0.0321 & $14.97^{* *}$ & $0.759^{\mathrm{ns}}$ & Yes & $\mathrm{Y}_{\mathrm{j}} \neq \mathrm{Y}_{1}$ \\
\hline
\end{tabular}

(1) According to the method proposed by Leite \& Oliveira (2002). ${ }^{(2)}$ Natural logarithm (NL). ** significant at $1 \%$. ns: not significant.

Table 2. Statistical model of the ratio between macronutrients $\left(\mathrm{g} \mathrm{kg}^{-1}\right)$ and micronutrients (mg kg-1) and DRIS indices. Norms were defined by two criteria [natural log transformation (NL) and $F$ value] of data of a reference population

\begin{tabular}{|c|c|c|c|}
\hline Nutrient & Norm & Statistical model & $\mathrm{R}^{2}$ \\
\hline \multicolumn{4}{|c|}{ Macronutrient } \\
\hline \multirow[t]{2}{*}{$\mathrm{N}$} & $\mathrm{NL}$ & $\mathrm{N}=45.3387+4.2423 * * \mathrm{I}_{\mathrm{N}}$ & 0.6097 \\
\hline & $\mathrm{F}$ value & $\mathrm{N}=45.3387+4.0230 * * \mathrm{I}_{\mathrm{N}}$ & 0.5987 \\
\hline \multirow[t]{2}{*}{$\mathrm{P}$} & NL & $\mathrm{P}=3.0390+0.6693 * * \mathrm{I}_{\mathrm{P}}$ & 0.8592 \\
\hline & F value & $\mathrm{P}=3.0390+0.6941 * * \mathrm{I}_{\mathrm{P}}$ & 0.8452 \\
\hline \multirow[t]{2}{*}{$\mathrm{K}$} & $\mathrm{NL}$ & $\mathrm{K}=20.8089+4.3555^{* *} \mathrm{I}_{\mathrm{K}}$ & 0.8640 \\
\hline & F value & $\mathrm{K}=20.8089+4.4115^{* *} \mathrm{I}_{\mathrm{K}}$ & 0.8565 \\
\hline \multirow[t]{2}{*}{$\mathrm{Ca}$} & $\mathrm{NL}$ & $\mathrm{Ca}=29.7813+7.4239^{* *} \mathrm{I}_{\mathrm{Ca}}$ & 0.8214 \\
\hline & F value & $\mathrm{Ca}=29.7813+7.2304^{* *} \mathrm{I}_{\mathrm{Ca}}$ & 0.8084 \\
\hline \multirow[t]{2}{*}{$\mathrm{Mg}$} & $\mathrm{NL}$ & $\mathrm{Mg}=4.4171+1.0542^{* *} \mathrm{I}_{\mathrm{Mg}}$ & 0.8524 \\
\hline & F value & $\mathrm{Mg}=4.4171+1.0118^{* *} \mathrm{I}_{\mathrm{Mg}}$ & 0.8474 \\
\hline \multirow[t]{2}{*}{$\mathrm{S}$} & NL & $\mathrm{S}=12.5970+6.4692^{* *} \mathrm{I}_{\mathrm{S}}$ & 0.9697 \\
\hline & F value & $\begin{array}{c}\mathrm{S}=12.5970+6.4565^{* *} \mathrm{I}_{\mathrm{S}} \\
\text { Micronutrient }\end{array}$ & 0.9162 \\
\hline \multirow{2}{*}{$\mathrm{B}$} & $\mathrm{NL}$ & $\mathrm{B}=66.4886+24.7756^{* *} \mathrm{I}_{\mathrm{B}}$ & 0.9292 \\
\hline & F value & $\mathrm{B}=66.4886+25.1729 * * \mathrm{I}_{\mathrm{B}}$ & 0.9156 \\
\hline \multirow{2}{*}{$\mathrm{Zn}$} & $\mathrm{NL}$ & $\mathrm{Zn}=28.0453+7.8985^{* *} \mathrm{I}_{\mathrm{Zn}}$ & 0.9002 \\
\hline & F value & $\mathrm{Zn}=28.0453+7.9399 * * \mathrm{I}_{\mathrm{Zn}}$ & 0.8937 \\
\hline \multirow{2}{*}{$\mathrm{Cu}$} & $\mathrm{NL}$ & $\mathrm{Cu}=15.9013+9.6290 * * \mathrm{I}_{\mathrm{Cu}}$ & 0.9734 \\
\hline & F value & $\mathrm{Cu}=15.9013+10.2203^{* *} \mathrm{I}_{\mathrm{Cu}}$ & 0.9779 \\
\hline \multirow{2}{*}{$\mathrm{Mn}$} & $\mathrm{NL}$ & $\mathrm{Mn}=52.1271+31.6732^{* *} \mathrm{I}_{\mathrm{Mn}}$ & 0.9421 \\
\hline & F value & $\mathrm{Mn}=52.1271+32.5993^{* *} \mathrm{I}_{\mathrm{Mn}}$ & 0.9424 \\
\hline \multirow{2}{*}{$\mathrm{Fe}$} & $\mathrm{NL}$ & $\mathrm{Fe}=108.3468+50.3119 * * \mathrm{I}_{\mathrm{Fe}}$ & 0.9657 \\
\hline & $\mathrm{F}$ value & $\mathrm{Fe}=108.3468+52.0092^{* *} \mathrm{I}_{\mathrm{Fe}}$ & 0.9599 \\
\hline
\end{tabular}

$* * \mathrm{p}<0.01$

was higher than 0.8090, p < 0.001, for most nutrients except $\mathrm{N}$, which had the lowest $\mathrm{R}^{2}[0.6097$ (NL) and 0.5987 (F value) ] but was significant $(\mathrm{p}<0.01)$ (Table 3).
The hypothesis of randomness of the results diagnosed as deficient was tested by chi- square (Table 4$)$. The test was effective $(\mathrm{p}<0.01)$ to prove that the results were not random but that the 
calculation of the DRIS system, using two criteria norms, was effective in diagnosing the nutritional status, rejecting the hypothesis that the deficiency had been randomly diagnosed by DRIS.
Urano et al. (2006) reported similar results in an evaluation of the nutritional status of soybean and Serra et al. (2010a, b) in an assessment of the nutritional status of cotton plants by the methods

Table 3. Beaufils ranges determined for the nutritional diagnosis of cotton plants based on DRIS norms (NL transformation and $\mathrm{F}$ value)

\begin{tabular}{|c|c|c|c|c|c|c|}
\hline Nutrient & Norm & Deficiency & Tendency to deficiency & Sufficient & Tendency to excess & Excess \\
\hline \multirow{3}{*}{$\mathrm{N}$} & & & & $\mathrm{g} \mathrm{kg}^{-1}$ & & \\
\hline & NL & $<42.5$ & $42.5-43.9$ & $43.9-46.7$ & $46.7-48.1$ & $>48.1$ \\
\hline & F value & $<42.6$ & $42.6-43.9$ & $43.9-46.7$ & $46.7-48.1$ & $>48.1$ \\
\hline \multirow[t]{2}{*}{$\mathrm{P}$} & NL & $<2.5$ & $2.5-2.8$ & $2.8-3.3$ & $3.3-3.5$ & $>3.5$ \\
\hline & F value & $<2.5$ & $2.5-2.8$ & $2.8-3.3$ & $3.3-3.5$ & $>3.5$ \\
\hline \multirow[t]{2}{*}{$\mathrm{K}$} & NL & $<17.2$ & $17.2-19.0$ & $19.0-22.6$ & $22.6-24.4$ & $>24.4$ \\
\hline & F value & $<17.2$ & $17.2-19.0$ & $19.0-22.6$ & $22.6-24.4$ & $>24.4$ \\
\hline \multirow[t]{2}{*}{$\mathrm{Ca}$} & NL & $<25.2$ & $25.2-27.5$ & $27.5-32.1$ & $32.1-34.4$ & $>34.4$ \\
\hline & $\mathrm{F}$ value & $<25.3$ & $25.3-27.5$ & $27.5-32.0$ & $32.0-34.3$ & $>34.3$ \\
\hline \multirow[t]{2}{*}{$\mathrm{Mg}$} & NL & $<3.6$ & $3.6-4.0$ & $4.0-4.8$ & $4.8-5.3$ & $>5.3$ \\
\hline & $\mathrm{F}$ value & $<3.6$ & $3.6-4.0$ & $4.0-4.8$ & $4.8-5.2$ & $>5.2$ \\
\hline \multirow[t]{2}{*}{$\mathrm{S}$} & NL & $<4.8$ & $4.8-8.7$ & $8.7-16.5$ & $16.5-20.4$ & $>20.4$ \\
\hline & $\mathrm{F}$ value & $<5.2$ & $5.2-8.9$ & $8.9-16.3$ & $16.3-20.0$ & $>20.0$ \\
\hline \multirow{3}{*}{ B } & & & & $\mathrm{mg} \mathrm{kg}^{-1}$ & & \\
\hline & NL & $<40.8$ & $40.8-53.6$ & $53.6-79.4$ & $79.4-92.2$ & $>92.2$ \\
\hline & F value & $<41.2$ & $41.2-53.8$ & $53.8-79.2$ & $79.2-91.8$ & $>91.8$ \\
\hline \multirow[t]{2}{*}{$\mathrm{Zn}$} & $\mathrm{NL}$ & $<21.7$ & $21.7-24.9$ & $24.9-31.2$ & $31.2-34.4$ & $>34.4$ \\
\hline & $\mathrm{F}$ value & $<21.8$ & $21.8-24.9$ & $24.9-31.2$ & $31.2-34.3$ & $>34.3$ \\
\hline \multirow[t]{2}{*}{$\mathrm{Cu}$} & NL & $<3.9$ & $3.9-9.8$ & $9.8-22.0$ & $22.0-27.9$ & $>27.9$ \\
\hline & $\mathrm{F}$ value & $<3.7$ & $3.7-9.8$ & $9.8-22.0$ & $22.0-28.1$ & $>28.1$ \\
\hline \multirow[t]{2}{*}{$\mathrm{Mn}$} & NL & $<14.9$ & $14.9-33.4$ & $33.4-70.8$ & $70.8-89.3$ & $>89.3$ \\
\hline & $\mathrm{F}$ value & $<14.9$ & $14.9-33.4$ & $33.4-70.8$ & $70.8-89.4$ & $>89.4$ \\
\hline \multirow[t]{2}{*}{$\mathrm{Fe}$} & $\mathrm{NL}$ & $<52.3$ & $52.3-80.2$ & $80.2-136.5$ & $136.5-164.4$ & $>164.4$ \\
\hline & $\mathrm{F}$ value & $<52.6$ & $52.6-80.4$ & $80.4-136.3$ & $136.3-164.1$ & $>164.1$ \\
\hline
\end{tabular}

Table 4. Chi-square test and values of observed and expected frequencies (\%) for $\mathrm{N}, \mathrm{P}, \mathrm{K}, \mathrm{Ca}, \mathrm{Mg}, \mathrm{S}, \mathrm{B}, \mathrm{Zn}$, $\mathrm{Cu}, \mathrm{Mn}$, and $\mathrm{Fe}$ as deficient nutrients by the DRIS method; norms transformed by natural $\log (\mathrm{NL})$ and $F$ value

\begin{tabular}{|c|c|c|c|c|c|c|}
\hline \multirow{2}{*}{ Nutrient } & \multicolumn{3}{|c|}{ DRIS-NL } & \multicolumn{3}{|c|}{ DRIS-F value } \\
\hline & $\mathrm{OF}^{(1)}$ & $E F^{(1)}$ & $(\mathrm{OF}-\mathrm{EF})^{2} / \mathrm{EF}$ & $\mathrm{OF}^{(1)}$ & $\mathrm{EF}^{(1)}$ & $(\mathrm{OF}-\mathrm{EF})^{2} / \mathrm{EF}$ \\
\hline $\mathrm{N}$ & 19.44 & 9.09 & 11.79 & 19.44 & 9.09 & 11.79 \\
\hline $\mathrm{P}$ & 7.41 & 9.09 & 0.31 & 7.41 & 9.09 & 0.31 \\
\hline $\mathrm{K}$ & 16.67 & 9.09 & 6.32 & 16.67 & 9.09 & 6.31 \\
\hline $\mathrm{Ca}$ & 19.44 & 9.09 & 11.78 & 19.44 & 9.09 & 11.79 \\
\hline $\mathrm{Mg}$ & 12.04 & 9.09 & 0.96 & 12.04 & 9.09 & 0.95 \\
\hline $\mathrm{S}$ & 2.78 & 9.09 & 4.38 & 7.41 & 9.09 & 0.31 \\
\hline $\mathrm{B}$ & 13.89 & 9.09 & 2.53 & 14.82 & 9.09 & 7.33 \\
\hline $\mathrm{Zn}$ & 25.0 & 9.09 & 27.84 & 25.93 & 9.09 & 31.18 \\
\hline $\mathrm{Cu}$ & 0 & 9.09 & 9.09 & 0 & 9.09 & 9.09 \\
\hline $\mathrm{Mn}$ & 0 & 9.09 & 9.09 & 0 & 9.09 & 9.09 \\
\hline $\mathrm{Fe}$ & 0.93 & 9.09 & 2.53 & 0.93 & 9.09 & 7.33 \\
\hline$\chi^{2}$ & & & $86.63 * *$ & & & $95.50 * *$ \\
\hline
\end{tabular}

(1) OF and EF: observed and expected frequencies, respectively. ${ }^{* *} \mathrm{p}<0.01$. 
DRIS and CND (Compositional Nutrient Diagnosis).

In the analysis of the nutritional status of the plots, $\mathrm{Zn}$ was most frequently diagnosed as deficient, followed by $\mathrm{Ca}$ and $\mathrm{N}$ (Table 6), with agreement between the criteria of norm establishment. However, S had the highest percentage of deficiencyprone plots (Table 5).

These tables of ideal nutrient ranges are only recommended in the regions where they were developed, for their use in other regions can produce unfavorable results. The same is true for the DRIS norms, because the Beaufils ranges are derived from statistical models based on DRIS procedures, indicated for specific regions. So far it has been observed that specific norms for each climate and soil region are more efficient than general norms for different regions. In view of the absence of universal norms, Silva et al. (2005) suggested the use of specific rather than of general norms.

The percentage of agreement of the diagnosed nutritional status was 74.07-100 \% among the plots evaluated (Table 6). Coincidence was lowest between the methods for S $(74.07 \%)$. However, the percentage of plots in which $\mathrm{S}$ deficiency was diagnosed was higher by the $\mathrm{F}$ value $(7.41 \%)$ than by the other criterion $(2.78 \%)$.

Table 5. Percentage of plots diagnosed by Beaufils ranges as deficiency, deficiency-prone, sufficient, excess-prone or excess leaf nutrient contents of cotton, based on the criteria of natural log transformation (NL) and F value

\begin{tabular}{|c|c|c|c|c|c|c|}
\hline Nutrient & Norm & Deficiency & Deficiency-prone & Sufficient & Excess-prone & Excess \\
\hline & \multicolumn{6}{|c|}{$\%$ of plots } \\
\hline \multirow[t]{2}{*}{$\mathrm{N}$} & NL & 19.44 & 15.74 & 38.89 & 9.26 & 16.67 \\
\hline & $\mathrm{F}$ value & 19.44 & 15.74 & 39.81 & 8.33 & 16.67 \\
\hline \multirow[t]{2}{*}{$\mathrm{P}$} & NL & 7.41 & 19.44 & 45.37 & 12.04 & 15.74 \\
\hline & $\mathrm{F}$ value & 7.41 & 19.44 & 45.37 & 12.04 & 15.74 \\
\hline \multirow[t]{2}{*}{$\mathrm{K}$} & NL & 16.67 & 14.81 & 44.44 & 13.89 & 10.19 \\
\hline & $\mathrm{F}$ value & 16.67 & 14.81 & 44.44 & 13.89 & 10.19 \\
\hline \multirow[t]{2}{*}{$\mathrm{Ca}$} & NL & 19.44 & 17.59 & 46.30 & 7.41 & 9.26 \\
\hline & $\mathrm{F}$ value & 19.44 & 17.59 & 43.52 & 10.19 & 9.26 \\
\hline \multirow[t]{2}{*}{$\mathrm{Mg}$} & NL & 12.04 & 9.26 & 31.48 & 18.52 & 28.70 \\
\hline & $\mathrm{F}$ value & 12.04 & 9.26 & 31.48 & 14.81 & 32.41 \\
\hline \multirow[t]{2}{*}{$\mathrm{S}$} & NL & 2.78 & 54.63 & 21.30 & 11.11 & 10.19 \\
\hline & $\mathrm{F}$ value & 7.41 & 50.93 & 20.37 & 2.78 & 18.52 \\
\hline \multirow[t]{2}{*}{ B } & NL & 13.89 & 33.33 & 32.41 & 9.26 & 11.11 \\
\hline & $\mathrm{F}$ value & 14.81 & 32.41 & 32.41 & 9.26 & 11.11 \\
\hline \multirow[t]{2}{*}{$\mathrm{Zn}$} & NL & 25.00 & 25.93 & 25.93 & 10.19 & 12.96 \\
\hline & $\mathrm{F}$ value & 25.93 & 25.00 & 25.93 & 8.33 & 14.81 \\
\hline \multirow[t]{2}{*}{$\mathrm{Cu}$} & NL & 0.00 & 36.11 & 42.59 & 11.11 & 10.19 \\
\hline & $\mathrm{F}$ value & 0.00 & 37.96 & 40.74 & 11.11 & 10.19 \\
\hline \multirow[t]{2}{*}{$\mathrm{Mn}$} & NL & 0.00 & 22.22 & 55.56 & 11.11 & 11.11 \\
\hline & $\mathrm{F}$ value & 0.00 & 22.22 & 55.56 & 11.11 & 11.11 \\
\hline \multirow[t]{2}{*}{$\mathrm{Fe}$} & NL & 0.93 & 37.04 & 50.00 & 2.78 & 9.26 \\
\hline & $\mathrm{F}$ value & 0.93 & 37.04 & 50.00 & 2.78 & 9.26 \\
\hline
\end{tabular}

Table 6. Frequency of plots with consistent diagnoses of the nutritional status, determined by the F value and natural log transformation (NL)

\begin{tabular}{|c|c|c|c|c|c|c|c|c|c|c|c|c|}
\hline Norm & $\mathbf{N}$ & $\mathbf{P}$ & $\mathbf{K}$ & $\mathbf{C a}$ & Mg & $\mathbf{S}$ & B & $\mathrm{Zn}$ & $\mathrm{Cu}$ & Mn & $\mathbf{F e}$ & Mean \\
\hline \multicolumn{13}{|c|}{$\%$} \\
\hline F value vs NL & 99.07 & 100 & 100 & 94.44 & 92.59 & 74.07 & 98.15 & 94.44 & 98.15 & 100 & 100 & 95.54 \\
\hline
\end{tabular}




\section{CONCLUSIONS}

1. The identity test confirmed that the methods of dual ratios to establish DRIS norms are not identical, i.e., the use of the $\mathrm{F}$ value or natural log transformation (NL) generates different estimates for DRIS indices.

2. Even when the norms are determined by different criteria [ $\mathrm{F}$ value and $\mathrm{NL}$, the assessment of the nutritional status by the method of Beaufils ranges converges, with diagnosis agreement of over $92.59 \%$, except for $\mathrm{S}$, with a coincidence of $74.07 \%$.

3. By the Beaufils ranges developed in this study, it is possible to diagnose the nutritional status of cotton plants in the southern region of Mato Grosso, by comparisons of nutrient levels in leaf samples.

\section{ACKNOWLEDGEMENTS}

The authors are indebted to the Brazilian Federal Agency for Support and Evaluation of Graduate Education - CAPES for the partial doctoral fellowship ("Sandwich Doctorate") of the first author at the Universidade Federal da Grande Dourados/ Escola Superior de Agricultura Luiz de Queiroz (UFGD/ESALQ/USP).

\section{LITERATURE CITED}

ALVAREZ V., V.H. \& LEITE, R.A. Fundamentos estatísticos das fórmulas usadas para cálculo dos índices DRIS. B. Inf. SBCS, 24:20-25, 1999.

BALDOCK, J.O. \& SCHULTE, E.E. Plant analysis with standardized scores combines DRIS and sufficiency range approaches for corn. Agron. J., 88:448-456, 1996.

BEAUFILS, E.R. Diagnosis and recommendation integrated system (DRIS). A general scheme of experimentation and calibration based on principles developed from research in plant nutrition. Pietermaritzburg, University of Natal, 1973. 132p. (Soil Science Bulletin, 1)

BEVERLY, R.B. A Practical Guide to the Diagnosis and Recommendation Integrated System (DRIS) Athens, Micro-Macro Publishing, 1991. 385p.

EMPRESA BRASILEIRA DE PESQUISA AGROPECUÁRIA EMBRAPA. Centro Nacional de Pesquisa de Solos (Rio de Janeiro, RJ). Sistema brasileiro de classificação de solos. Brasília: 2006. 169p.

GRAYBILL, F.A. Theory and application of the linear model. Belmonte: Wadsworth Publishing Company, 1976. 704p.
GUINDANI, R.H.P.; ANGHINONI, I. \& NACHTIGALL, G.R. DRIS na avaliação do estado nutricional do arroz irrigado por inundação. R. Bras. Ci. Solo, 33:109-118, 2009.

JONES, C.A. Proposed modifications of the diagnosis and recommendation integrated system (DRIS) for interpreting plant analyses. Comm. Soil Sci. Plant Anal., 12:785-794, 1981.

LEITE, H.G. \& OLIVEIRA, F.H.T. Statistical procedure to test identity between analytical methods. Comm. Soil Sci. Plant Anal., 33:1105-1118, 2002.

LETZSCH, W.S. Computer program for selection of norms for use in the diagnosis and recommendation integrated system (DRIS). Comm. Soil Sci. Plant Anal., 16:339-347, 1985.

MALAVOLTA, E.; VITTI, G.C. \& OLIVEIRA, S.A. Princípios, métodos e técnicas de avaliação do estado nutricional. In: MALAVOLTA, E.; VITTI, G.C. \& OLIVEIRA, S.A., eds. Avaliação do estado nutricional de plantas: princípios e aplicações. 2.ed. Piracicaba, Potafos, 1997. p.115-230.

MALAVOLTA, E. Manual de nutrição mineral de plantas. São Paulo, Agronômica Ceres, 2006. 638p.

MARUR, C.J. \& RUANO, O. A reference system for determination of developmental stages of upland cotton. R. Oleaginosa Fibrosa, 5:313-317, 2001.

MICROSOFT CORPORATION: Excel Software. Redmond, Microsoft Corp., 2010.

NACHTIGALL, G.R. \& DECHEN, A.R. DRIS norms for evaluating the nutritional state of apple tree. Sci. Agric., 64:282$287,2007 \mathrm{~b}$

REIS JÚNIOR, R.A.; CORRÊA, J.B.; CARVALHO, J.G.C. \& GUIMARÃES, P.T.G. Estabelecimento de normas DRIS para o cafeeiro no sul de minas gerais: $1^{\mathrm{a}}$ aproximação. Ci. Agrotecnol., 26:269-282, 2002.

RIBEIRO JÚNIOR, J.I. Análise estatística no SAEG. Viçosa, MG, Universidade Federal de Viçosa. 2001. 301p.

SERRA, A.P.; MARCHETTI, M.E.; VITORINO, A.C.T.; NOVELINO, J.O. \& CAMACHO, M.A. Desenvolvimento de normas DRIS e CND e avaliação do estado nutricional da cultura do algodoeiro. R. Bras. Ci. Solo, 34:97-104, 2010a.

SERRA, A.P.; MARCHETTI, M.E.; VITORINO, A.C.T.; NOVELINO, J.O. \& CAMACHO, M.A. Determinação de faixas normais de nutrientes no algodoeiro pelos métodos CHM, CND e DRIS. R. Bras. Ci. Solo, 34:105-113, 2010 b.

SILVA, G.G.C.; NEVES, J.C.L. \& ALVAREZ V., V.H. Avaliação da universalidade das normas DRIS, M- DRIS e CND. R. Bras. Ci. Solo, 29:755-761, 2005.

SILVEIRA, C.P.; NACHTIGALL, G.R. \& MONTEIRO, F.A. Norms for the diagnosis and recommendation integrated system for signal grass. Sci. Agric., 62:513-519, 2005a. 
SILVEIRA, C.P.; NACHTIGALL, G.R. \& MONTEIRO, F.A. Testing and validation of methods for the diagnosis and recommendation integrated system for signal grass. Sci. Agric., 62:520-527, 2005b.

URANO, E.O.M.; KURIHARA, C.H.; MAEDA, S.; VITORINO, A.C.T., GONÇALVES, M.C. \& MARCHETTI, M.E. Avaliação do estado nutricional da soja. Pesq. Agropec. Bras., 41:1421-1428, 2006.

URANO, E.O.M.; KURIHARA, C.H.; MAEDA, S.; VITORINO, A.C.T.; GONÇALVES, M.C. \& MARCHETTI, M.E. Determinação de teores ótimos de nutrientes em soja pelos métodos chance matemática, sistema integrado de diagnose e recomendação e diagnose da composição nutricional. $R$. Bras. Ci. Solo, 31:63-72, 2007.
WADT, P.G.S.; NOVAIS, R.F.; ALVAREZ V., V.H.; FONSECA, S.; BARROS, N.F. \& DIAS, L.E. Três métodos de cálculo do DRIS para avaliar o potencial de resposta à adubação de árvores de eucalipto. R. Bras. Ci. Solo, 22:661-666, 1998.

WALWORTH, J.L. \& SUMNER, M.E. The diagnosis and recommendation integrated system (DRIS). Adv. Soil Sci., 6:149-188, 1987. 
